Y. Kobayashi $\cdot$ K. Naruse $\cdot$ Y. Hamada $\cdot$ E. Nakashima $\cdot$

K. Kato $\cdot$ N. Akiyama $\cdot$ H. Kamiya $\cdot$ A. Watarai $\cdot$

M. Nakae $\cdot$ Y. Oiso $\cdot$ J. Nakamura

\title{
Human proinsulin C-peptide prevents proliferation of rat aortic smooth muscle cells cultured in high-glucose conditions
}

Received: 14 December 2004 / Accepted: 29 June 2005 / Published online: 30 September 2005

C) Springer-Verlag 2005

\begin{abstract}
Aims/hypothesis: Proinsulin C-peptide is involved in several biological activities. However, the role of C-peptide in vascular smooth muscle cells is unclear. We therefore investigated its effects, in vascular smooth muscle cells in high-glucose conditions. Methods: Rat aortic smooth muscle cells were cultured with 5.5 or $20 \mathrm{mmol} / 1$ glucose with or without C-peptide (1 to $100 \mathrm{nmol} / \mathrm{l}$ ) for 3 weeks. Proliferation activities, the protein expression of platelet-derived growth factor (PDGF)-beta receptor, the phosphorylation of $\mathrm{p} 42 / \mathrm{p} 44$ mitogen-activated protein (MAP) kinases, and glucose uptake were measured. Results: The proliferation activities increased approximately three-fold under high-glucose conditions $(p<0.05)$. C-peptide suppressed hyperproliferation activities that were induced by high glucose. This happened in a dose-dependent manner from 1 to $100 \mathrm{nmol} / \mathrm{l}$ of C-peptide. Cpeptide (10 and $100 \mathrm{nmol} / \mathrm{l})$ inhibited the increased protein expression of PDGF-beta receptor and the phosphorylation of p42/p44 MAP kinases that had been induced by high glucose $(p<0.05)$. Furthermore, $100 \mathrm{nmol} / 1$ of $\mathrm{C}$-peptide augmented the impaired glucose uptake in the high-glucose
\end{abstract}

\footnotetext{
Y. Kobayashi · Y. Hamada · E. Nakashima · N. Akiyama ·

H. Kamiya $\cdot$ A. Watarai $\cdot$ M. Nakae $\cdot$ Y. Oiso ·

J. Nakamura $(\bowtie)$

Division of Metabolic Diseases,

Department of Internal Medicine,

Nagoya University Graduate School of Medicine,

65 Tsuruma-cho, Showa-ku,

Nagoya 466-8550, Japan

e-mail: jiro@med.nagoya-u.ac.jp

Tel.: +81-52-7442187

Fax: $+81-52-7442206$

K. Naruse

Department of Internal Medicine,

Aichi-Gakuin University School of Dentistry,

Nagoya, Japan

\section{K. Kato}

Division of Endocrinology,

Metabolism and Diabetology,

Department of Internal Medicine,

Aichi Medical University School of Medicine,

Aichi, Japan
}

conditions. Conclusions/interpretation: These observations suggest that C-peptide could prevent diabetic macroangiopathy by inhibiting smooth muscle cell growth and ameliorating glucose utilisation in smooth muscle cells. C-peptide may thus be a novel agent for treating diabetic macroangiopathy in patients with type 1 and type 2 diabetes.

Keywords Aortic smooth muscle cells · C-peptide · Diabetes - Mitogen-activated protein kinase .

Platelet-derived growth factor

Abbreviations FBS: Fetal bovine serum - MAP: Mitogen-activated protein PDGF: Platelet-derived growth factor - SMC: Smooth muscle cell - VSMC: Vascular smooth muscle cell

\section{Introduction}

C-peptide is a 31-amino-acid peptide that is cleaved from the processing of proinsulin to insulin. For decades, Cpeptide was considered to have no biological effects. But recently, many investigators have revealed that the administration of C-peptide reduced the glomerular filtration rate and restored nerve functions and blood flow in diabetic animals or type 1 diabetic patients [1-8]. Moreover, the administration of C-peptide elicits a substantial increase in whole-body glucose turnover in diabetic rats $[9,10]$.

In the vasculature, the effects of C-peptide are controversial. C-peptide induces vasodilation via the increased production of nitric oxide from vascular endothelial cells [11-14]. On the other hand, C-peptide accumulates in the vessel wall in early atherogenesis in diabetic animals and patients and stimulates chemotaxis of monocytes/CD4 ${ }^{+}$ cells, subsequently migrating into the vessel wall $[15,16]$. To date the effect of C-peptide on vascular smooth muscle cells (VSMCs) has not been reported. Since the migration and proliferation of VSMCs are the essential pathological changes in diabetic macroangiopathy, it is vital to assess the effects of C-peptide on VSMCs. 
One of the mechanisms by which the growth of VSMCs is increased in atherosclerotic lesions is elevated sensitivity to platelet-derived growth factor (PDGF). Walker and coworkers reported that VSMCs in atherosclerotic lesions showed increasing expression of the PDGF-beta receptor and produced PDGF-like molecules [17]. We, and others, have reported that the growth rate of cultured VSMCs under high-glucose conditions was elevated via increased protein expression of PDGF-beta receptor [18-21]. In addition, it has been demonstrated that PDGF stimulates cell growth and migration via the $\mathrm{p} 42 / \mathrm{p} 44$ mitogen-activated protein (MAP) kinase pathway in VSMCs [22].

The aim of this study is to reveal the role of C-peptide in VSMCs. Using a culture system, we investigated whether the administration of C-peptide affects proliferation, expression of the PDGF-beta receptor, phosphorylation of the p42/p44 MAP kinases, and glucose transport activities in VSMCs under high-glucose conditions.

\section{Materials and methods}

Materials Reagents were obtained from the following sources: rat aortic smooth muscle cells (SMCs) (A10 cells) from the American Type Culture Collection (Manassas, VA, USA); DMEM, penicillin-streptomycin, and FBS from Gibco (Grand Island, NY, USA). Human C-peptide was kindly provided by Eli Lilly (Indianapolis, IN, USA). Scrambled human C-peptide (the same amino acid residues as in C-peptide, but assembled in random order) was from Sigma Genosys (Cambridge, UK). Whatman GF/C filters were from Whatman International (Maidstone, UK). Rabbit anti-human PDGF-beta receptor antibody, and rabbit antihuman p42/p44 MAP kinase antibody came from Upstate Biotechnology (Lake Placid, NY, USA). Rabbit antiphospho-human p42/p44 MAP kinase was supplied by Cell Signaling Technology (Beverly, MA, USA). Chemiluminescence detection kits and $\left[{ }^{3} \mathrm{H}\right]$-thymidine came from Amersham Pharmacia Biotech (Buckinghamshire, UK).

Cell culture Rat aortic SMCs (A10 cells) were grown in DMEM containing $5.5 \mathrm{mmol} / \mathrm{l}$ glucose and $10 \% \mathrm{FBS}, \mathrm{pH}$ 7.4 , at $37^{\circ} \mathrm{C}$ in a humidified $5 \% \mathrm{CO}_{2} / 95 \%$ air atmosphere. Third or fourth passage cells from the purchase were grown for 3 weeks in DMEM containing 5.5 or $20 \mathrm{mmol} / 1$ glucose with or without C-peptide or scrambled C-peptide (1 to $100 \mathrm{nmol} / \mathrm{l})$, and were used in subsequent experiments. For experiments with acute stimulation with C-peptide, cells were serum-starved overnight and stimulated with C-peptide or scrambled C-peptide for $10 \mathrm{~min}$.

Assay of proliferation activities in SMCs Cells were plated on six-well plates at a density of $1 \times 10^{4}$ cells $/ \mathrm{cm}^{2}$ and grown in each experimental medium as described above. The proliferation activity in SMCs was assessed by determining $\left[{ }^{3} \mathrm{H}\right]$-thymidine incorporation into DNA as previously described [23].
Immunoblot analyses After incubation with each experimental medium for the indicated periods, cells were washed three times with ice-cold PBS and lysed in a buffer containing $50 \mathrm{mmol} / 1$ Tris- $\mathrm{HCl}, \mathrm{pH} 7.4,1 \%$ Triton X-100, $0.25 \%$ sodium deoxycholate, $150 \mathrm{mmol} / 1 \mathrm{NaCl}, 1 \mathrm{mmol} / \mathrm{l}$ EGTA, $1 \mathrm{mmol} / \mathrm{l}$ phenylmethylsulphonyl fluoride, $1 \mu \mathrm{g} / \mathrm{ml}$ aprotinin, $1 \mu \mathrm{g} / \mathrm{ml}$ leupeptin, $1 \mathrm{mmol} / 1 \mathrm{Na}_{3} \mathrm{VO}_{4}$, and $1 \mathrm{mmol} / 1 \mathrm{NaF}$ at $4^{\circ} \mathrm{C}$. Samples containing the same amount of protein were electrophoresed on SDS-PAGE and transferred to a nitrocellulose membrane. The membrane was incubated overnight at $4^{\circ} \mathrm{C}$ with the first antibody, followed by incubation with an HRP-conjugated anti-rabbit polyclonal IgG antibody. The proteins were visualised using ECL chemiluminescence detection kits. Protein expression was quantified by densitometry.

Assay of glucose transport activities in SMCs After 3 weeks of culture in normal or high-glucose conditions with or without C-peptide, unlabelled and labelled 2-deoxyglucose $(0.1 \mathrm{mmol} / 1,0.74 \mathrm{kBq} /$ well $)$ were added to the cells in the PBS buffer $\left(138 \mathrm{mmol} / \mathrm{l} \mathrm{NaCl}, 8.1 \mathrm{mmol} / 1 \mathrm{Na}_{2} \mathrm{HPO}_{4}\right.$, $2.6 \mathrm{mmol} / 1 \mathrm{KCl}, 0.5 \mathrm{mmol} / 1 \mathrm{MgSO}_{4}, 0.1 \mathrm{mmol} / 1 \mathrm{CaCl}_{2}$, $1.5 \mathrm{mmol} / 1 \mathrm{KH}_{2} \mathrm{PO}_{4}$, at $\mathrm{pH} 7.4$ ) with $1 \%$ BSA. The cells were then incubated for $6 \mathrm{~min}$ at $37^{\circ} \mathrm{C}$. The reaction was stopped by washing the cells three times with ice-cold PBS. The cells were solubilised in $1 \mathrm{ml}$ of solution. Radioactivity was quantified using a liquid scintillation counter (LSC-5100; Aloka, Tokyo, Japan).

Statistical analysis Results were expressed as means \pm SEM. Statistical analyses were made by one-way ANOVA with the Bonferroni correction for multiple comparisons. A $p$ value of $p<0.05$ was considered statistically significant.

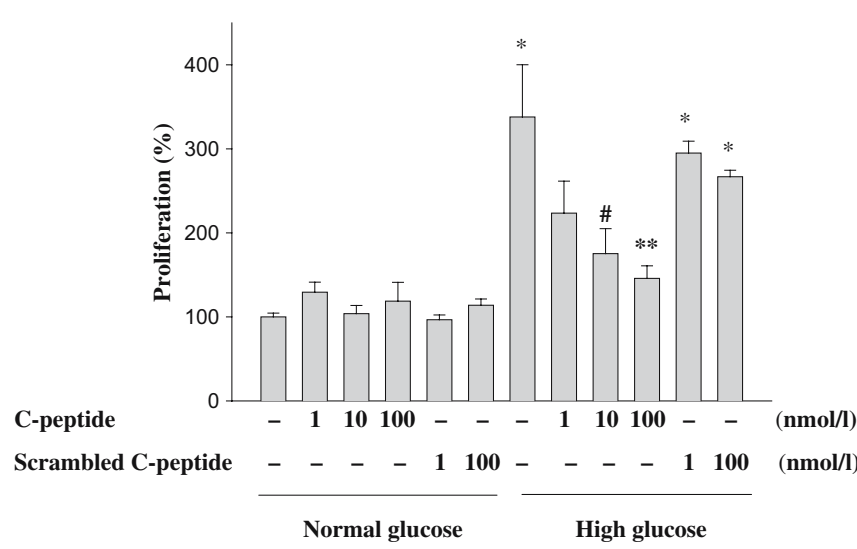

Fig. 1 The proliferation activities in SMCs. SMCs were treated with C-peptide or scrambled C-peptide for 3 weeks under the normal $(5.5 \mathrm{mmol} / \mathrm{l})$ or high $(20 \mathrm{mmol} / \mathrm{l})$ glucose conditions. Values are means \pm SEM from a representative experiment of 4-6 experiments. Each experiment was performed in triplicate. ${ }^{*} p<0.05$ vs $5.5 \mathrm{mmol} / 1$ glucose without C-peptide and scrambled C-peptide; ${ }_{p}^{\#}<0.05$ vs $20 \mathrm{mmol} / 1$ glucose without C-peptide and scrambled Cpeptide; $* * p<0.01$ vs $20 \mathrm{mmol} / 1$ glucose without C-peptide and scrambled C-peptide 
Fig. 2 Protein expression of SMCs were treated with C-peptide or scrambled C-peptide for 3 weeks under the normal $(5.5 \mathrm{mmol} / \mathrm{l})$ or high $(20 \mathrm{mmol} / \mathrm{l})$ glucose conditions. a Representative immunoblots. b Protein expression as increase from control. Values are means \pm SEM of three different experiments. $* p<0.05$ vs $5.5 \mathrm{mmol} / 1$ glucose without C-peptide and scrambled C-peptide; ${ }^{*} p<0.05$ vs 20 mmol/1 glucose without $\mathrm{C}$-peptide and scrambled C-peptide; ${ }^{* *} p<0.01$ vs $20 \mathrm{mmol} / 1$ glucose without C-peptide PDGF-beta receptor in SMCs. C-peptide and scrambled

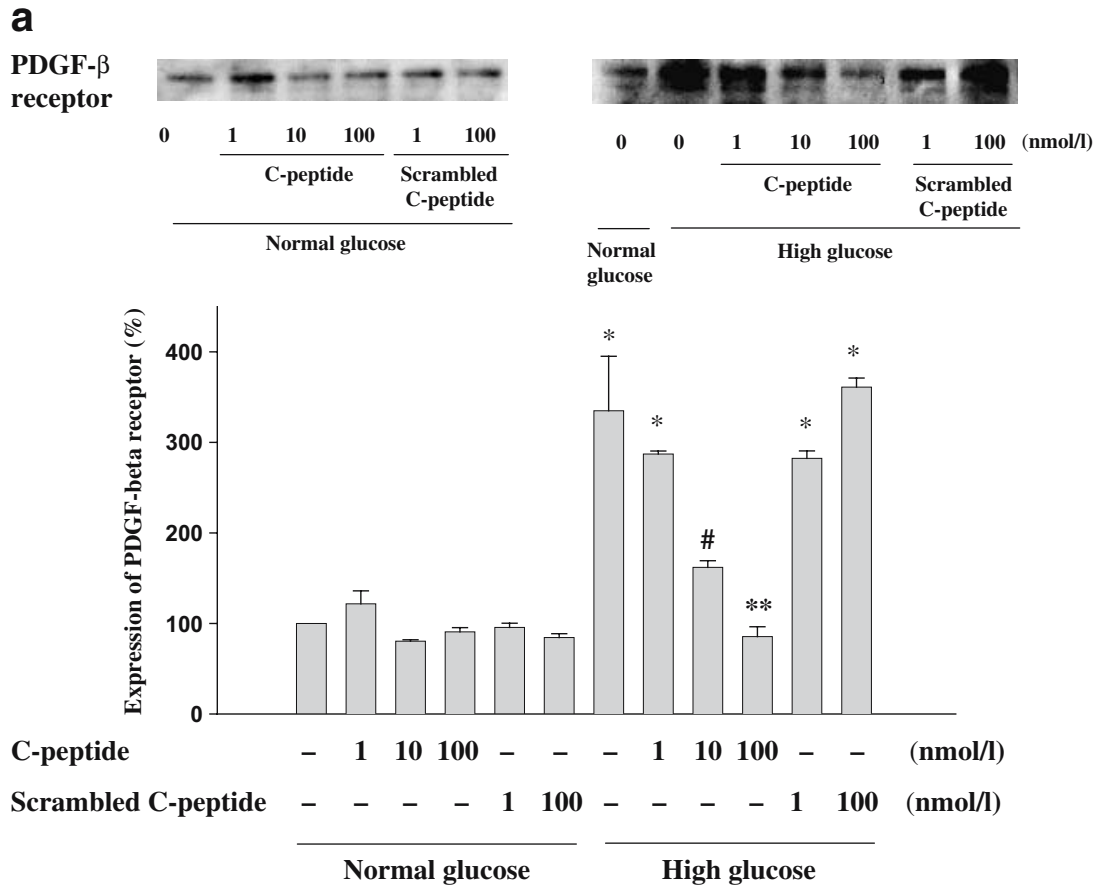

\section{Results}

Effects of C-peptide on proliferation activities of SMCs As shown in Fig. 1, the proliferation activities of SMCs under high-glucose conditions increased by $3.38 \pm 0.62$-fold compared with SMCs in normal glucose conditions $(p<0.05)$. The 3-week administration of C-peptide suppressed the glucose-induced increase of thymidine incorporation in a dose-dependent manner (C-peptide, $1 \mathrm{nmol} / \mathrm{l}: 33.9 \pm 11.2 \%$, $10 \mathrm{nmol} / \mathrm{l}: 48.1 \pm 8.7 \%(p<0.05), 100 \mathrm{nmol} / \mathrm{l}: 56.9 \pm 4.4 \%$, $p<0.01$; reduction in comparison with high-glucose con- trol). In contrast, C-peptide had no effects on the proliferation activities of SMCs under the normal glucose conditions. Scrambled C-peptide had no effects either under the normal or the high-glucose conditions.

Effects of C-peptide on protein expression of PDGF-beta receptor in SMCs Protein expression of PDGF-beta receptor increased by $3.35 \pm 0.60$-fold under the high-glucose conditions $(p<0.05)$ (Fig. 2). The 3-week administration of Cpeptide suppressed the glucose-induced increase of protein expression of PDGF-beta receptor in a dose-dependent
Fig. 3 Phosphorylation of p42/p44 MAP kinases in SMCs. SMCs were treated with C-peptide or scrambled C-peptide for 3 weeks under normal $(5.5 \mathrm{mmol} / \mathrm{l})$ or high $(20 \mathrm{mmol} / \mathrm{l})$ glucose conditions. a Representative immunoblots. b, c Increase in phosphorylation of p42 and p44, respectively. Values are shown as means \pm SEM of three different experiments. ${ }^{*} p<0.05$ vs $5.5 \mathrm{mmol} / \mathrm{l}$ glucose without C-peptide and scrambled C-peptide; ${ }^{\#} p<0.05$ vs $20 \mathrm{mmol} / 1$ glucose without C-peptide and scrambled C-peptide a

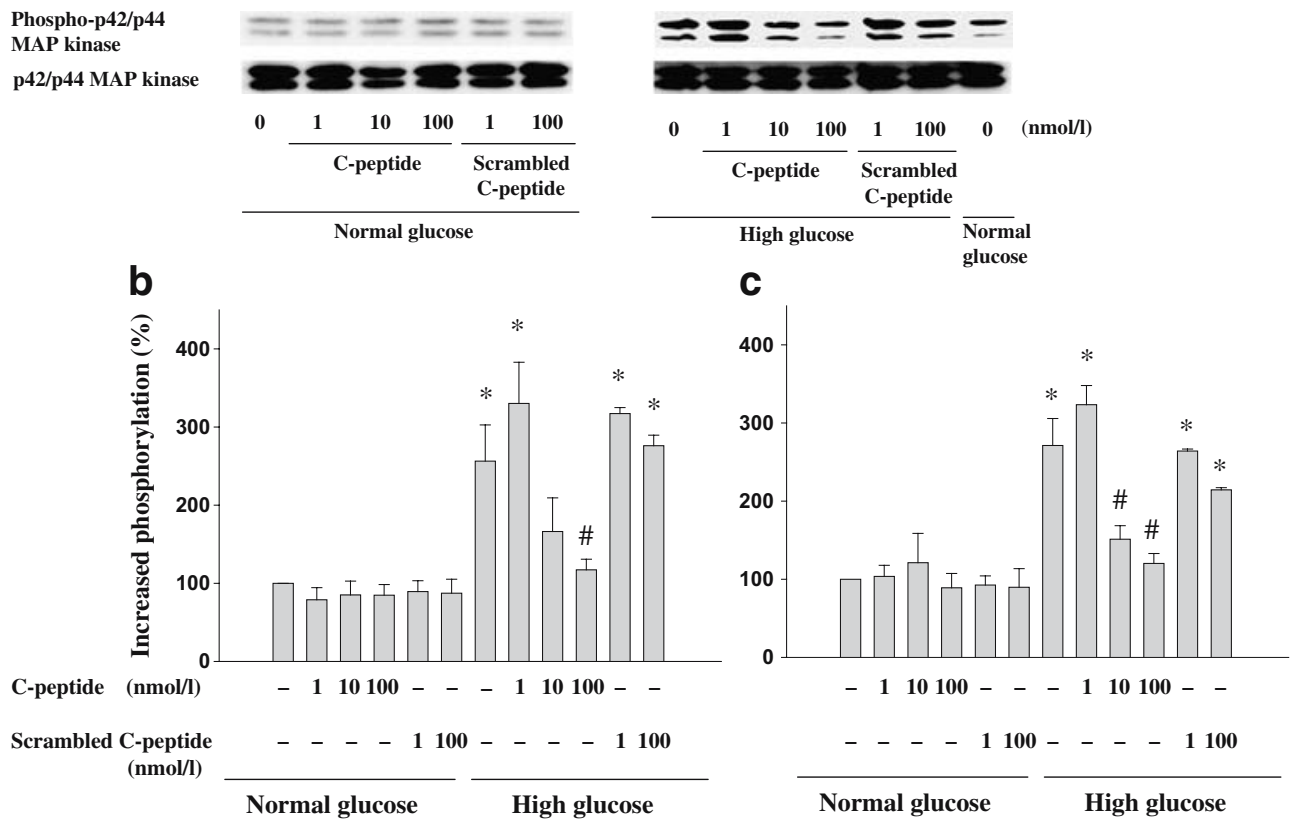




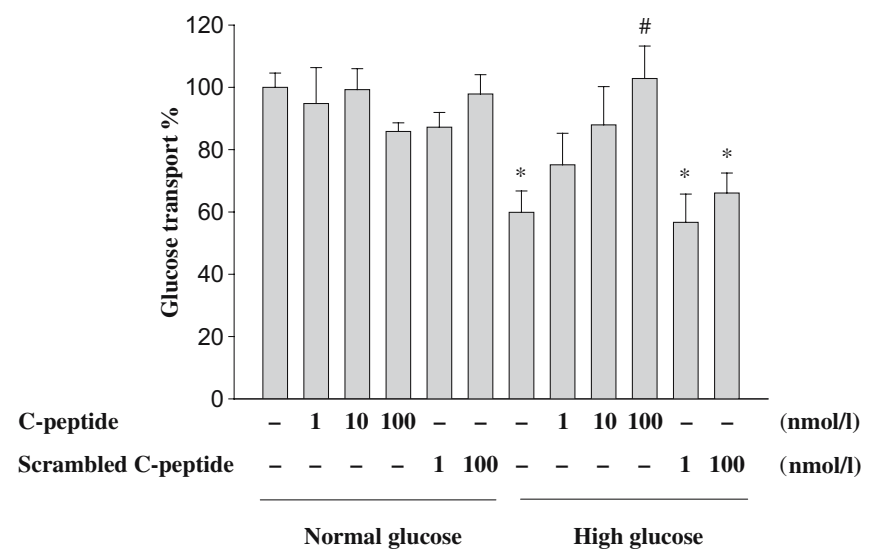

Fig. 4 Glucose transport activities in SMCs. After 3 weeks of culture under normal $(5.5 \mathrm{mmol} / \mathrm{l})$ or high $(20 \mathrm{mmol} / \mathrm{l})$ glucose conditions with C-peptide or scrambled C-peptide, unlabelled and labelled 2-deoxyglucose were added and incubated for $6 \mathrm{~min}$. Results are expressed as percentage of control and shown as means \pm SEM of three different experiments. ${ }^{*} p<0.05$ vs $5.5 \mathrm{mmol} / 1$ glucose without C-peptide and scrambled C-peptide; ${ }^{\#} p<0.05$ vs $20 \mathrm{mmol} / 1$ glucose without $\mathrm{C}$-peptide and scrambled C-peptide

manner. The administration of 10 and $100 \mathrm{nmol} / \mathrm{l}$ of $\mathrm{C}$ peptide led to a significant decrease compared with highglucose control cultures. Neither C-peptide under the normal glucose conditions, nor scrambled C-peptide under the normal and high-glucose conditions affected protein expression of PDGF-beta receptor.

Effects of C-peptide on activation of p 42/p44 MAP kinases in SMCs After 3 weeks, the activities of p42 and p44 MAP kinases in SMCs cultured in high-glucose conditions were elevated compared with those in SMCs in the normal glucose conditions (increase: $2.56 \pm 0.46$ and $2.71 \pm 0.35$ fold, respectively, $p<0.05$, Fig. 3 ). The administration of Cpeptide (10 and $100 \mathrm{nmol} / \mathrm{l}$ ) for 3 weeks reduced the increase in phosphorylation of $\mathrm{p} 42 / \mathrm{p} 44$ MAP kinases that had been induced by high glucose $(p<0.05)$. However, Cpeptide did not affect phosphorylation of p42/p44 MAP kinase under the normal glucose conditions. Scrambled Cpeptide had no effects, either in the normal, or in the highglucose conditions.

Effects of C-peptide on glucose transport activities of SMCs Glucose uptake was decreased in SMCs cultured in high-glucose conditions (decrease: $40.1 \pm 6.9 \%$, compared with SMCs in normal glucose conditions, $p<0.05$ ) (Fig. 4). Treatment with C-peptide reversed, in a dose-dependent manner, the decrease in glucose uptake that had been in- duced by high glucose, with $100 \mathrm{nmol} / 1$ of C-peptide ameliorating glucose uptake by $71.6 \pm 17.4 \%$ in the highglucose conditions $(p<0.05)$. However, C-peptide did not affect glucose uptake in the normal glucose conditions. Scrambled C-peptide had no effects, either in normal or in high-glucose conditions.

Effects of acute exposure to C-peptide on p42/p44 MAP kinases To examine the acute effects of C-peptide in SMCs, cells were incubated with $0.3-100 \mathrm{nmol} / 1$ of Cpeptide for $10 \mathrm{~min}$. As shown in Fig. 5, acute exposure to C-peptide or scrambled C-peptide did not affect phosphorylation of p42/p44 MAP kinases in SMCs.

\section{Discussion}

The results presented in this study indicate that C-peptide inhibits the following effects that are induced by high glucose in SMCs: hyperproliferation, increased protein expression of PDGF-beta receptor, and increased phosphorylation of $\mathrm{p} 44 / \mathrm{p} 42$ MAP kinases. These results suggest that C-peptide suppresses the growth of SMCs that is induced by high glucose via inhibition of the PDGFbeta receptor/p44/42 MAP kinases pathway. Our results also showed that C-peptide reversed the impairment of glucose utilisation in SMCs under high-glucose conditions.

C-peptide is cleaved from proinsulin and co-secreted with insulin in response to glucose stimulation. Insulin has been reported to accelerate SMC growth and promote atherosclerosis via the activation of p44/42 MAP kinases [24-27]. The proliferation of SMCs is one of the major pathological changes in atherosclerotic lesions occurring in the diabetic state [28]. Increased expression of PDGF-beta receptor has been demonstrated in atherosclerotic lesions and SMCs cultured under high-glucose conditions [19]. Because insulin increases the expression of PDGF-beta receptor and stimulates the growth of SMCs, its unbeneficial effects on atherosclerosis have been controversial in the treatment of diabetic patients. Here, our results indicate that C-peptide has an opposite effect to that of insulin on the growth of SMCs. We have shown that C-peptide inhibited the high-glucose-induced growth of SMCs in a dose-dependent manner. Moreover, C-peptide also suppressed protein expression of PDGF-beta receptor and phosphorylation of p42/p44 MAP kinases, doing this dosedependently at concentrations of 10 to $100 \mathrm{nmol} / \mathrm{l}$. It is interesting that insulin and C-peptide, which are secreted at the same time from the pancreatic beta cell, have opposite
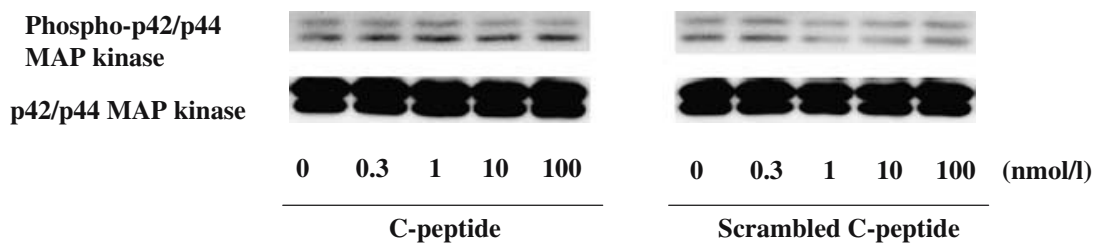

Fig. 5 The acute effects of C-peptide or scrambled C-peptide on the phosphorylation of p42/p44 MAP kinases in SMCs. Cells were serumstarved overnight and stimulated with C-peptide or scrambled C-peptide for 10 min. Representative immunoblots are shown 
effects on the growth of SMCs. C-peptide could play an important role in preventing SMC proliferation. Moreover, because the inhibitory effects of C-peptide on SMC growth occur in a dose-dependent manner, our results suggest that the additional administration of C-peptide to diabetic patients may inhibit the development of diabetic macroangiopathy.

Our results show that the chronic administration of human C-peptide produced significant effects in rat SMCs, the maximum effect being observed at $100 \mathrm{nmol} / 1$ of $\mathrm{C}$ peptide. On the other hand, Henriksson and colleagues [29] showed that specific binding of C-peptide to the cell membranes of human skin fibroblast gave full saturation at approximately $0.9 \mathrm{nmol} / \mathrm{l}$, and another team reported that lower concentrations of rat II C-peptide, such as 0.3$3.0 \mathrm{nmol}$ C-peptide, had a maximum effect on MAP kinase in rat skeletal myoblasts [30]. Since we used human Cpeptide in rat SMCs, one of the probable reasons why the higher concentrations of C-peptide were required to obtain the significant effects is the difference in the species of Cpeptide, which is consistent with a previous report demonstrating that a 1,000-fold increase in the concentrations of human C-peptide, compared with rat II C-peptide, was needed to achieve maximum effects on rat tissues [8].

The acute exposure with human C-peptide at concentrations of 1 to $100 \mathrm{nmol} / \mathrm{l}$ did not activate $\mathrm{p} 42 / \mathrm{p} 44 \mathrm{MAP}$ kinases in rat SMCs in our study. Since our preliminary study had shown that human C-peptide phosphorylated MAP kinase at concentrations of 0.3 to $100 \mathrm{nmol} / \mathrm{l}$ in human SMCs (data not shown), the discrepancy in the effects of Cpeptide between rat and human SMCs is probably the result of the difference in the species. However, there is a substantial homology between rat and human C-peptide [1]. Moreover, the chronic effects of C-peptide in SMCs under normal or high-glucose conditions in this study cannot be compared with the acute effects of C-peptide. Further studies are required to address these questions.

In our study, $1 \mathrm{nmol} / 1$ of C-peptide tended to inhibit SMC growth without suppressing PDGF-beta receptor expression or MAP kinase activities. Although one of the major pathways stimulating SMC growth is the PDGF/MAP kinase pathway, other mechanisms may also be affected by C-peptide. Further studies are underway in our laboratory.

Zierath and co-workers [31] reported that C-peptide stimulates the rate of glucose transport in a dose-dependent manner in isolated human skeletal muscle strips in vitro. In clinical studies, C-peptide increased whole-body glucose turnover $[9,10]$. Here, we have demonstrated that Cpeptide increased glucose utilisation in a dose-dependent manner in SMCs under high-glucose conditions. This is consistent with previous reports with other types of tissues. However, it remains unknown what role this effect of Cpeptide on glucose metabolism plays in the proliferation of SMCs.

In summary, chronic administration of C-peptide ameliorated high-glucose-induced hyperproliferation via suppression of a PDGF-beta receptor/MAP kinase pathway and high-glucose-induced suppression of glucose uptake in SMCs. This suggests that C-peptide may suppress atherosclerosis in diabetic patients. Concentrations of C-peptide differ in type 2 diabetic patients. In patients with insulin resistance, C-peptide is increased, whereas it is decreased in patients with insulin deficiency. Although the precise mechanisms of C-peptide's effects are still unclear, our results suggest $\mathrm{C}$-peptide could be useful in the treatment of atherosclerosis, not only in C-peptide-deficient type 1 diabetic patients, but also in some type 2 diabetic patients who have a relative deficiency of C-peptide.

Acknowledgements This work was supported in part by a Diabetes Research Grant from the Ministry of Health and Welfare of Japan. The authors thank Y. Maehata for technical assistance.

\section{References}

1. Ido Y, Vindigni A, Chang K et al (1997) Prevention of vascular and neural dysfunction in diabetic rats by C-peptide. Science 277:563-566

2. Johansson BL, Borg K, Fernqvist-Forbes E, Odergren T, Remahl S, Wahren J (1996) C-peptide improves autonomic nerve function in IDDM patients. Diabetologia 39:687-695

3. Johansson J, Ekberg K, Shafqat J et al (2002) Molecular effects of proinsulin C-peptide. Biochem Biophys Res Commun 295:1035-1040

4. Samnegard B, Jacobson SH, Jaremko G, Johansson BL, Sjoquist M (2001) Effects of C-peptide on glomerular and renal size and renal function in diabetic rats. Kidney Int 60:1258-1265

5. Samnegard B, Jacobson SH, Johansson BL et al (2004) C-peptide and captopril are equally effective in lowering glomerular hyperfiltration in diabetic rats. Nephrol Dial Transplant 19:1385-1391

6. Sima AA, Zhang W, Sugimoto K et al (2001) C-peptide prevents and improves chronic type I diabetic polyneuropathy in the BB/Wor rat. Diabetologia 44:889-897

7. Sjoquist M, Huang W, Johansson BL (1998) Effects of C-peptide on renal function at the early stage of experimental diabetes. Kidney Int 54:758-764

8. Zhang W, Yorek M, Pierson CR, Murakawa Y, Breidenbach A, Sima AA (2001) Human C-peptide dose-dependently prevents early neuropathy in the BB/Wor-rat. Int J Exp Diabetes Res 2:187-193

9. Li L, Oshida Y, Kusunoki M et al (1999) Rat C peptide I and II stimulate glucose utilization in STZ-induced diabetic rats. Diabetologia 42:958-964

10. Wu W, Oshida Y, Yang WP et al (1996) Effect of C-peptide administration on whole-body glucose utilization in STZinduced diabetic rats. Acta Physiol Scand 57:253-258

11. Johansson BL, Wahren J, Pernow J (2003) C-peptide increases forearm blood flow in patients with type 1 diabetes via a nitric oxide-dependent mechanism. Am J Physiol Endocrinol Metab 285:E864-E870

12. Kitamura T, Kimura K, Makondo K et al (2003) Proinsulin C-peptide increases nitric oxide production by enhancing mitogen-activated protein-kinase-dependent transcription of endothelial nitric oxide synthase in aortic endothelial cells of Wistar rats. Diabetologia 46:1698-1705

13. Jensen ME, Messina EJ (1999) C-peptide induces a concentration-dependent dilation of skeletal muscle arterioles only in presence of insulin. Am J Physiol 276:H1223-H1228

14. Stevens MJ, Zhang W, Li F, Sima AA (2004) C-peptide corrects endoneurial blood flow but not oxidative stress in type 1 BB/Wor rats. Am J Physiol Endocrinol Metab 287:E497E505

15. Marx N, Walcher D, Raichle C et al (2004) C-peptide colocalizes with macrophages in early arteriosclerotic lesions of diabetic subjects and induces monocyte chemotaxis in vitro. Arterioscler Thromb Vasc Biol 124:540-545 
16. Walcher D, Aleksic M, Jerg V et al (2004) C-peptide induces chemotaxis of human CD4-positive cells: involvement of pertussis toxin-sensitive G-proteins and phosphoinositide 3-kinase. Diabetes 53:1664-1670

17. Walker LN, Bowen-Pope DF, Ross R, Reidy MA (1986) Production of platelet-derived growth factor-like molecules by cultured arterial smooth muscle cells accompanies proliferation after arterial injury. Proc Natl Acad Sci U S A 83:7311-7315

18. Kasuya Y, Nakamura J, Hamada Y et al (1999) An aldose reductase inhibitor prevents the glucose-induced increase in PDGF-beta receptor in cultured rat aortic smooth muscle cells. Biochem Biophys Res Commun 261:853-858

19. Kawano M, Koshikawa T, Kanzaki T, Morisaki N, Saito Y, Yoshida S (1993) Diabetes mellitus induces accelerated growth of aortic smooth muscle cells: association with overexpression of PDGF beta-receptors. Eur J Clin Invest 23:84-90

20. Nakamura J, Kasuya Y, Hamada Y et al (2001) Glucoseinduced hyperproliferation of cultured rat aortic smooth muscle cells through polyol pathway hyperactivity. Diabetologia 44: 480-487

21. Tamura K, Kanzaki T, Tashiro J et al (2000) Increased atherogenesis in Otsuka Long-Evans Tokushima fatty rats before the onset of diabetes mellitus: association with overexpression of PDGF beta-receptors in aortic smooth muscle cells. Atherosclerosis 149:351-358

22. Dubey RK, Gillespie DG, Imthurn B, Rosselli M, Jackson EK, Keller PJ (1999) Phytoestrogens inhibit growth and MAP kinase activity in human aortic smooth muscle cells. Hypertension 33:177-182

23. Naruse K, Sakakibara F, Nakamura J, Koh N, Hotta N (1996) Enhancement and inhibition of mitogenic action of insulin-like growth factor I by high glucose in cultured bovine retinal pericytes. Life Sci 58:267-276
24. Banskota NK, Taub R, Zellner K, King GL (1989) Insulin, insulin-like growth factor I and platelet-derived growth factor interact additively in the induction of the protooncogene c-myc and cellular proliferation in cultured bovine aortic smooth muscle cells. Mol Endocrinol 3:1183-1190

25. Huang B, Dreyer T, Heidt M et al (2002) Insulin and local growth factor PDGF induce intimal hyperplasia in bypass graft culture models of saphenous vein and internal mammary artery. Eur J Cardiothorac Surg 21:1002-1008

26. Kazama Y, Noguchi T, Kanemaru Y, Wakasugi M, Onaya T, Yoshida Y (1989) Effect of insulin on the production of prostacyclin and cell proliferation in cultured smooth muscle cells. Prostaglandins Leukot Essent Fatty Acids 37:129-134

27. Wang CC, Gurevich I, Draznin B (2003) Insulin affects vascular smooth muscle cell phenotype and migration via distinct signaling pathways. Diabetes 52:2562-2569

28. Miller RA, Wilson RB (1984) Atherosclerosis and myocardial ischemic lesions in alloxan-diabetic rabbits fed a low cholesterol diet. Arteriosclerosis 4:586-591

29. Henriksson M, Pramanik A, Shafqat J et al (2001) Specific binding of proinsulin C-peptide to intact and to detergentsolubilized human skin fibroblasts. Biochem Biophys Res Commun 280:423-427

30. Grunberger G, Qiang X, Li Z et al (2001) Molecular basis for the insulinomimetic effects of C-peptide. Diabetologia 44: $1247-1257$

31. Zierath JR, Galuska D, Johansson BL, Wallberg-Henriksson H (1991) Effect of human C-peptide on glucose transport in in vitro incubated human skeletal muscle. Diabetologia 34:899 901 